\title{
Baseline Levels of Siderastrea siderea Bleaching under Normal Environmental Conditions in Little Cayman
}

\author{
Samantha Banks ${ }^{1}$, Kristi Foster ${ }^{2}$ \\ ${ }^{1}$ University of Redlands, Redlands, CA, USA \\ ${ }^{2}$ Coastal \& Marine Ecology Consultants, Dania Beach, FL, USA \\ Email: Samantha_Banks@redlands.edu,kfoster@coastalmarineecology.com
}

How to cite this paper: Banks, S. and Foster, K. (2017) Baseline Levels of Siderastrea siderea Bleaching under Normal Environmental Conditions in Little Cayman. Open Journal of Marine Science, 7, 142154.

http://dx.doi.org/10.4236/ojms.2017.71011

Received: November 22, 2016

Accepted: January 17, 2017

Published: January 20, 2017

Copyright (c) 2017 by authors and Scientific Research Publishing Inc. This work is licensed under the Creative Commons Attribution International License (CC BY 4.0).

http://creativecommons.org/licenses/by/4.0/ (c) (i) Open Access

\begin{abstract}
This study describes the health status of Siderastrea siderea in Little Cayman before, during, and after the 2015 Caribbean-wide elevated temperature anomaly. Colony color was used as a proxy for health during snorkel and scuba surveys of shallow $(<2$ $\mathrm{m}$ depth) and deep (6-16 $\mathrm{m}$ depth) reefs. Baseline demographics indicated that $6 \%$ of this species were pale or blue pre-disturbance. When seawater temperatures exceeded $30.5^{\circ} \mathrm{C}, S$. siderea were early indicators of reef stress and among the first corals to bleach. Depth and site resilience did not significantly impact temperature susceptibility; however, smaller colonies $\left(<200 \mathrm{~cm}^{2}\right.$ surface area) were more likely to change color than the larger size classes. Little Cayman's $S$. siderea were capable of surviving large-scale ( $>80 \%)$ bleaching: mortality was observed for only one colony. Resilience rates varied considerably: one-third of the impacted population returned to the normal brown color within two months, one-third required 3 - 9 months to recover, and the fates of the remaining one-third remain to be determined. If the return to normal color is indicative of resistance to reef disturbances, $S$. siderea may be among the "winning" coral species following elevated temperature anomalies which are predicted to occur with increasing frequency and severity as a result of climate change.
\end{abstract}

\section{Keywords}

Siderastrea siderea, Bleaching Events, Demographic Study, Little Cayman, Caribbean

\section{Introduction}

Coral bleaching occurs when the long term average sea surface temperature (SST) is exceeded by $1^{\circ} \mathrm{C}$ or more during the warmest season [1]. With even a minimal rise in SST of $0.1^{\circ} \mathrm{C}$, the geographic extent and intensity of coral bleaching may be increased 
by $35 \%$ and $42 \%$, respectively [2]. As tropical ocean temperatures are rising by $0.07^{\circ} \mathrm{C}$ $0.5^{\circ} \mathrm{C}$ per decade, corals already near their thermal threshold are exposed to increasingly greater risk for bleaching [3]. In 2015, alerts warning of potential global-scale coral bleaching due to prolonged elevated seawater temperatures were broadcast among the scientific community. Bleaching threats continued through 2016. For example, Australia's Great Barrier Reef experienced extensive coral mortality, in what is considered one of the worst-case mass bleaching events on record, resulting from prolonged exposure to SSTs that were $1.0^{\circ} \mathrm{C}-1.5^{\circ} \mathrm{C}$ higher than the long term summertime average [4].

In the Caribbean, Little Cayman is an ideal location to study best-case scenario responses of corals to elevated temperatures: it is a remote, low elevation, flat island (10 square miles) with a small population ( $<200$ people) and without agriculture, runoff from rivers or streams, industry, and ports; providing the rare opportunity to decouple anthropogenic and environmental effects on the health of coral reefs. A Coral Reef Early Warning System (CREWS) buoy is moored above the reef on the north side of the island and records SST data along with other environmental parameters inside the eastern boundary of the Bloody Bay Marine Protected Area. Like many reefs around the world, Little Cayman's corals experienced bleached when exposed to above average SSTs in 2015.

Siderastrea siderea, commonly known as the massive starlet coral, is an abundant reef building coral in both shallow and deep Caribbean waters and is resilient when exposed to several non-ideal conditions [5]. Although $S$. siderea has been shown to have a stable relationship with its symbionts [6], it is one of the first species to bleach, making it a useful early indicator of disturbance events [7]. S. siderea has been observed to turn blue and other fluorescent colors as a stress response. $S$. siderea frequently survives bleaching events [8] [9] although colonies may remain blue for extended periods after the environmental stress conditions have dissipated.

This study describes the health status of $S$. siderea before, during, and after the 2015 Caribbean-wide elevated temperature anomaly as well as during 2016 "normal" (nondisturbance) temperatures. These data may subsequently be used to compare the health of $S$. siderea during normal conditions, bleaching events, and post-stress recovery periods. Knowing how certain coral species react to and recover from bleaching events is helpful in monitoring the resilience of coral reef ecosystems.

\section{Methods}

\subsection{Rapid Assessment}

Baseline surveys were conducted at five Little Cayman dive sites (6 - $16 \mathrm{~m}$ depth) within Bloody Bay Marine Park (Figure 1, Table 1) in June, 2015 before water temperatures reached the summer maximum. At each location, the color of $S$. siderea colonies was recorded along four 25-m line transects. Coral color was coded as: $1=$ white, bleached; 2 = blue or other fluorescent color, bleached; 3 = partially bleached; 4 = brown/tan, unbleached. Site data were pooled to determine the pre-disturbance population of stressed (Codes 1 - 3) and healthy (Code 4) colonies.

Coral color was recorded at seven dive sites (6-16 m depth) within and eastward of 


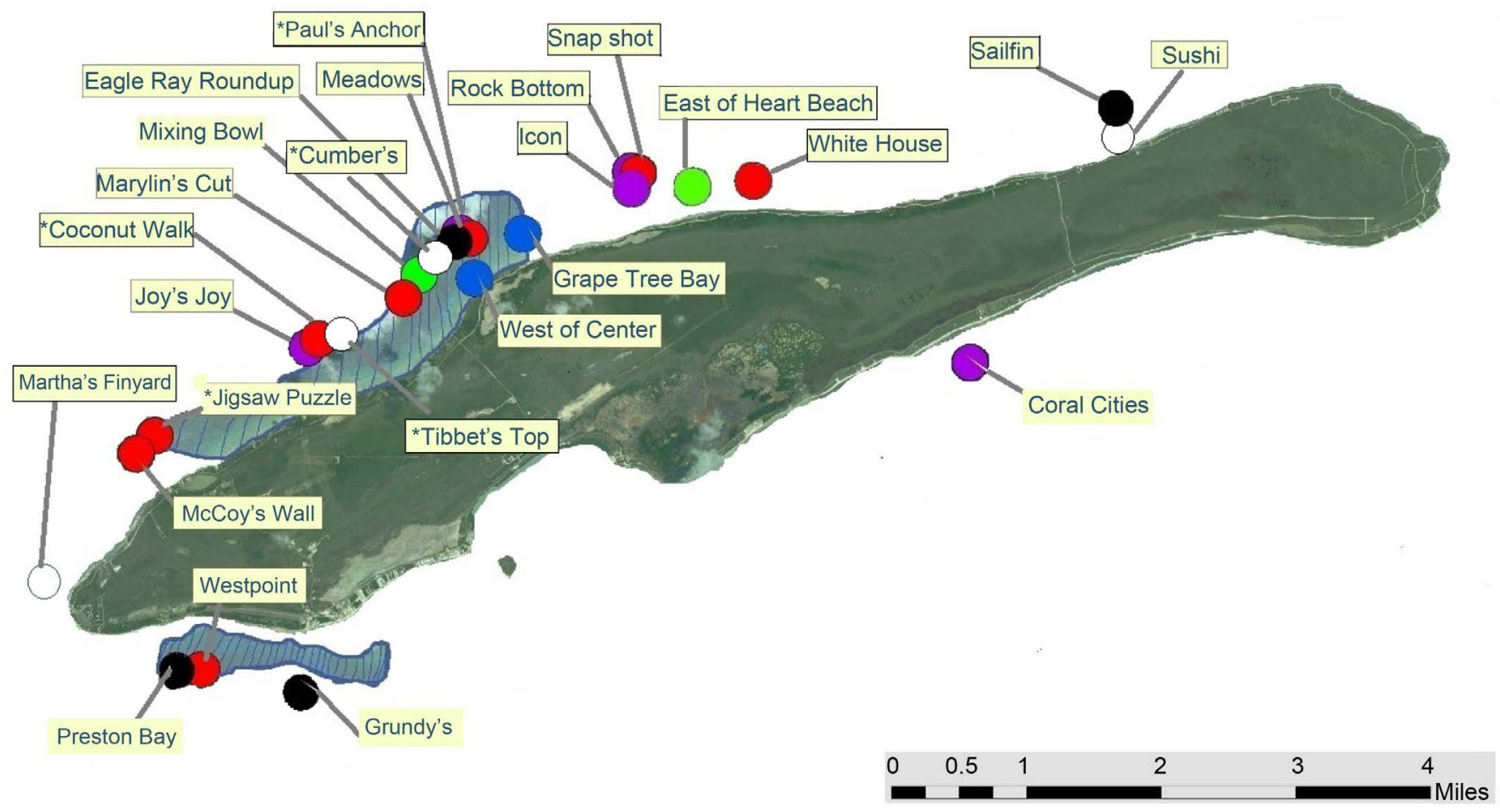

Figure 1. Map of Siderastrea siderea survey sites around Little Cayman. Colors represent Bray-Curtis similarity groupings during 2016 "normal" environmental conditions. Marine Protected areas are marked in striped blue. No spatial pattern is discernible based on these assemblages. White sites were not surveyed in 2016 and therefore were not included in the Bray-Curtis similarity test. The five baseline sites surveyed in June 2015, before water temperatures reached summer maximum are marked with asterisks.

Bloody Bay Marine Park in September and October, 2015 during the peak water temperatures to determine the population health during the bleaching event.

Coral color was recorded at three dive sites (6 - $16 \mathrm{~m}$ depth) and two shallow snorkel sites ( $<2 \mathrm{~m}$ depth) in November and December, 2015 when water temperatures were at or below the baseline survey temperatures to determine the population health during the first two months of post-bleaching recovery.

\subsection{Demographic Surveys}

Siderastrea siderea colony color was recorded at 21 sites around Little Cayman (Figure 1 , Table 1) in June-July 5, 2016, before water temperatures reached the summer maximum, using a roving diver technique [10] whereby a minimum of 32 colonies per site were photographed with a digital underwater camera positioned directly above each colony to record its planar view. A meter stick with marks every 10 centimeters was placed next to the colony to use for scale during subsequent image analysis and size class determination.

Coral Point Count (CPCe) [11] was used to calculate the surface area of each $S$. siderea colony within the digital images (Figure 2). Colonies were grouped into six size classes based on the surface area of live tissue (Table 2). 
Table 1. Survey sites around Little Cayman. Baseline survey sites from June 2015 are marked by asterisks.

\begin{tabular}{|c|c|c|c|c|c|c|c|}
\hline Survey Site & $\begin{array}{l}\text { Depth } \\
\text { (Deep/ } \\
\text { Shallow) }\end{array}$ & $\begin{array}{l}\text { Relative } \\
\text { Resilience } \\
\text { Level }\end{array}$ & $\begin{array}{l}\text { Inside/ } \\
\text { Outside } \\
\text { MPA }\end{array}$ & $\begin{array}{l}\text { June } \\
2015 \\
\text { Surveys }\end{array}$ & $\begin{array}{l}\text { Sept-Oct } \\
2015 \\
\text { Surveys }\end{array}$ & $\begin{array}{l}\text { Nov-Dec } \\
2015 \\
\text { Surveys }\end{array}$ & $\begin{array}{l}\text { Jun-Jul } \\
2016 \\
\text { Surveys }\end{array}$ \\
\hline Coconut Walk* & Deep & Med-high & Outside & $\mathrm{X}$ & $\mathrm{X}$ & & $\mathrm{X}$ \\
\hline Coral City & Deep & Low & Outside & & & $\mathrm{X}$ & $\mathrm{X}$ \\
\hline Cumber's* & Deep & Med-high & & $\mathrm{X}$ & & & \\
\hline $\begin{array}{l}\text { Eagle Ray } \\
\text { Roundup }\end{array}$ & Deep & Med-high & Inside & & & & $\mathrm{X}$ \\
\hline $\begin{array}{l}\text { Eastof Heart } \\
\text { Beach }\end{array}$ & Shallow & Med-low & Outside & & & & $\mathrm{X}$ \\
\hline Grape Tree Bay & Shallow & Med-high & Inside & & & $\mathrm{X}$ & $\mathrm{X}$ \\
\hline $\begin{array}{l}\text { Grundy's } \\
\text { Garden }\end{array}$ & Deep & Med-high & Outside & & & $\mathrm{X}$ & $\mathrm{X}$ \\
\hline Icon & Deep & Med-high & Outside & & $\mathrm{X}$ & & $\mathrm{X}$ \\
\hline Jigsaw Puzzle* & Deep & Med-high & Outside & $\mathrm{X}$ & & & $\mathrm{X}$ \\
\hline Joy's Joy & Deep & Med-high & Outside & & & & $\mathrm{X}$ \\
\hline $\begin{array}{l}\text { Martha's } \\
\text { Finyard }\end{array}$ & Deep & High & Outside & & $\mathrm{X}$ & & \\
\hline Marylin's Cut & Deep & Med-high & Inside & & & & $\mathrm{X}$ \\
\hline McCoy's Wall & Shallow & Med-high & Outside & & & & $\mathrm{X}$ \\
\hline Meadows & Deep & Med-high & Inside & & & & $\mathrm{X}$ \\
\hline Mixing Bowl & Deep & Med-high & Inside & & $\mathrm{X}$ & & $\mathrm{X}$ \\
\hline $\begin{array}{l}\text { Paul's } \\
\text { Anchors* }\end{array}$ & Deep & Med-high & Inside & $\mathrm{X}$ & $\mathrm{X}$ & & $\mathrm{X}$ \\
\hline Preston Bay & Shallow & Low & Inside & & & & $\mathrm{X}$ \\
\hline Rock Bottom & Deep & Med-low & Outside & & $\mathrm{X}$ & & $\mathrm{X}$ \\
\hline Sailfin & Deep & Med-low & Outside & & & & $\mathrm{X}$ \\
\hline Snapshot & Deep & Med-low & Outside & & $\mathrm{X}$ & & $\mathrm{X}$ \\
\hline Sushi & Shallow & Med-Low & Outside & & & $\mathrm{X}$ & \\
\hline Tibbet's Top ${ }^{*}$ & Deep & Med-high & Outside & $\mathrm{X}$ & & & \\
\hline West of Center & Shallow & Med-high & Inside & & & & $\mathrm{X}$ \\
\hline Westpoint & Deep & Low & Inside & & & $\mathrm{X}$ & $\mathrm{X}$ \\
\hline White House & Shallow & Med-low & Outside & & & & $\mathrm{X}$ \\
\hline
\end{tabular}

Table 2. Size class groupings based on surface area of live tissue (2016).

\begin{tabular}{ccc}
\hline Size Class & Surface Area $\left(\mathrm{cm}^{2}\right)$ & \% of Surveyed Population \\
\hline SC1 & $<200$ & $39 \%$ \\
SC2 & $200-400$ & $17 \%$ \\
SC3 & $400-600$ & $12 \%$ \\
SC4 & $600-800$ & $7 \%$ \\
SC5 & $800-1000$ & $5 \%$ \\
SC6 & $>1000$ & $20 \%$ \\
\hline
\end{tabular}




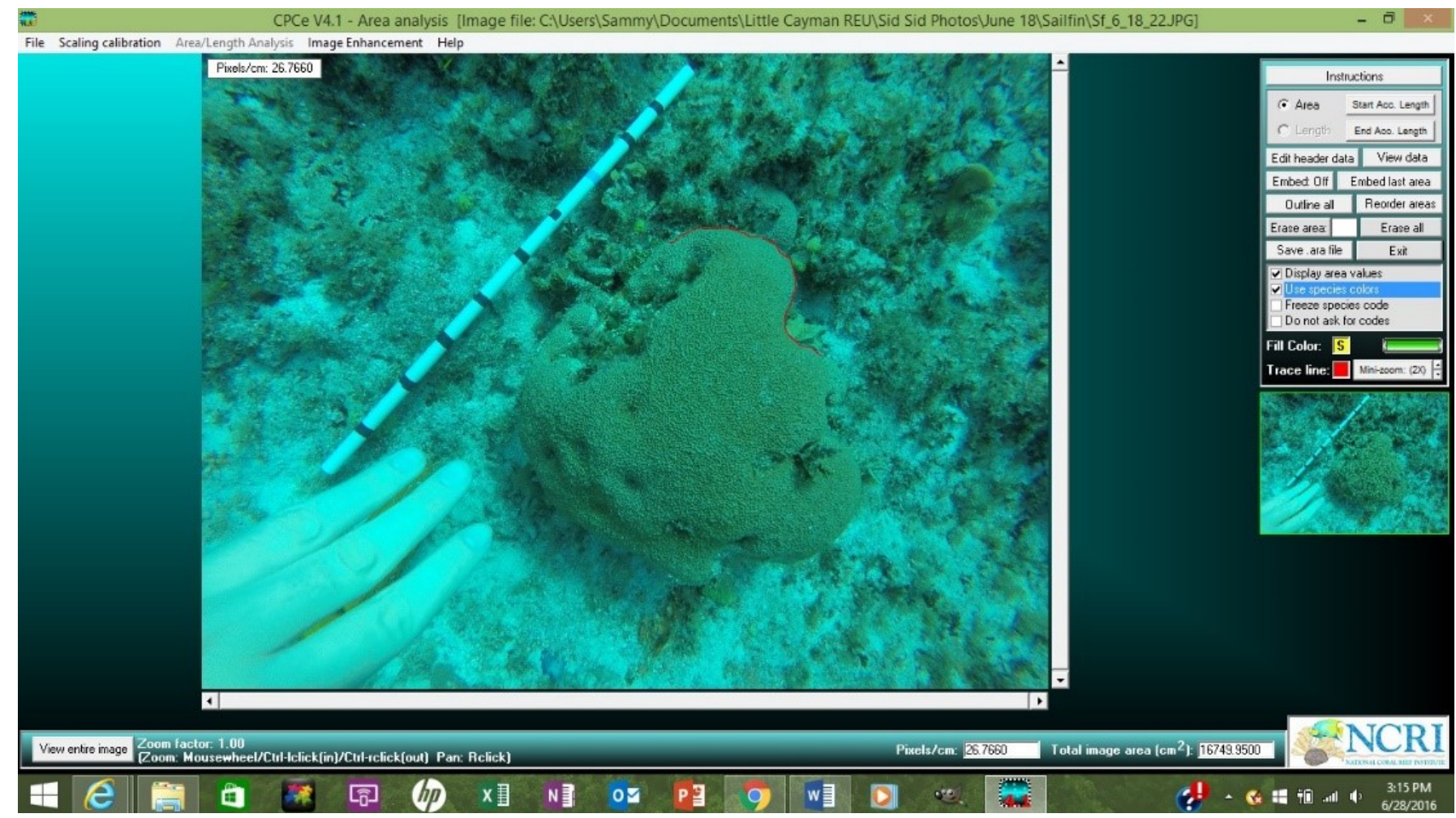

Figure 2. Image analysis of $S$. siderea colony to determine surface area using CPCe. The meter stick provides scale for the colony surface area and size class determination. The number of fingers in the image represents the coded health status of the colony.

Spatial comparisons of the unhealthy $S$. siderea colonies around Little Cayman were conducted using Primer software [12]. Data were organized by size class and survey site. A fourth root transformation was performed to minimize the effect of any large differences between zero and non-zero values during analysis. A triangular similarity matrix was created and used to calculate the Bray-Curtis Similarity index between sites [13]. A hierarchical agglomerative cluster analysis [13] was used to create assemblages with $\geq 70 \%$ within-group similarity.

Non-parametric, one-way, pair-wise analysis of similarity (ANOSIM) tests determined whether sites were statistically significantly different [13] based on depth and on site resilience. Site resilience was determined during a previous study (unpublished data) based on six indicators of coral reef resilience: coral diversity, macroalgae cover, coral cover, bleaching resistance, coral recruitment, temperature variability, and herbivore biomass. Similarity of percentages (SIMPER) tests determined which size classes contributed most to similarities within and dissimilarities between site groupings [13].

Wilcoxon-Mann-Whitney tests were performed to comparethe health status of $S$. sidereabefpre, during, and after exposure to the elevated seawater temperatures and between size classes.

\subsection{Sea Surface Temperatures}

Twice daily SSTs recorded by the Little Cayman CREWS buoy in the 06:00 and 18:00 hours are archived in NOAA's open access Coral Health and Monitoring Program (CHAMP) Portal database [14]. The 18:00 hour data from July-October in 2014, 2015, 
and 2016 were plotted to provide annual comparisons of the SSTs during the months when coral bleaching alerts for the Caribbean were issued by NOAA (Figure 3 ).

\section{Results}

In June 2015, when maximum water temperatures surrounding Little Cayman's reefs were $29^{\circ} \mathrm{C}, 6 \%$ of the $S$. siderea colonies were pale or blue (Figure 4 ), thereby establishing the pre-disturbance baseline of stressed colonies within a "normal" population. No colonies were fully bleached (white) and no tissue loss or recent mortality was observed.

Between August and October, water temperatures around the reef (6 - $16 \mathrm{~m}$ depth) frequently exceeded the local typical summertime maximum of $30.5^{\circ} \mathrm{C}$ (Figure 3) [14], causing wide-scale paling and bleaching. $82 \%$ of the observed $S$. siderea colonies, or an additional $76 \%$ beyond the baseline, displayed signs of stress (Figure 4): $23 \%$ were pale,

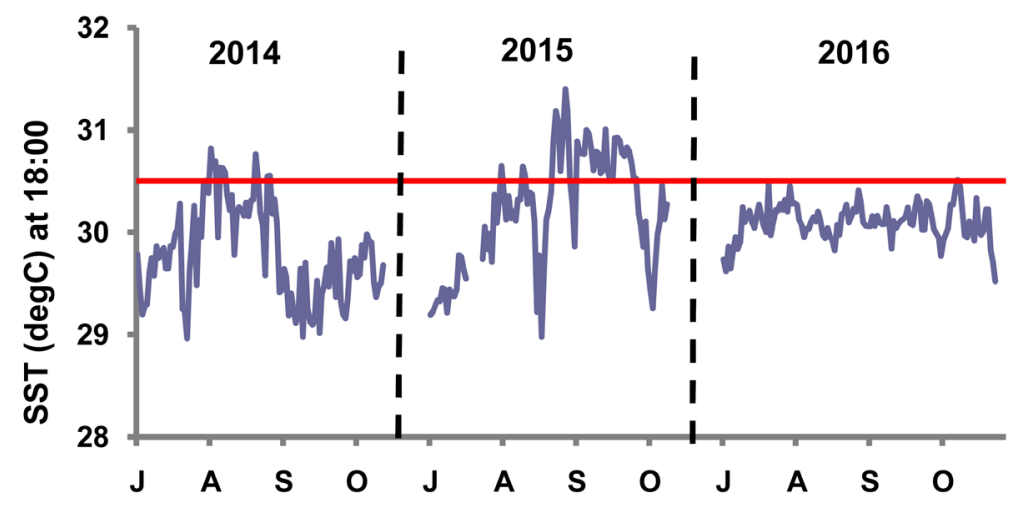

Figure 3. Temporal comparison of SST in Little Cayman during 2014-2016 bleaching alert periods. Data courtesy of NOAA's open access CHAMP Portal database. Red line indicates normal summertime maximum temperature in Little Cayman $\left(30.5^{\circ} \mathrm{C}\right)$ below which widespread bleaching does not occur.

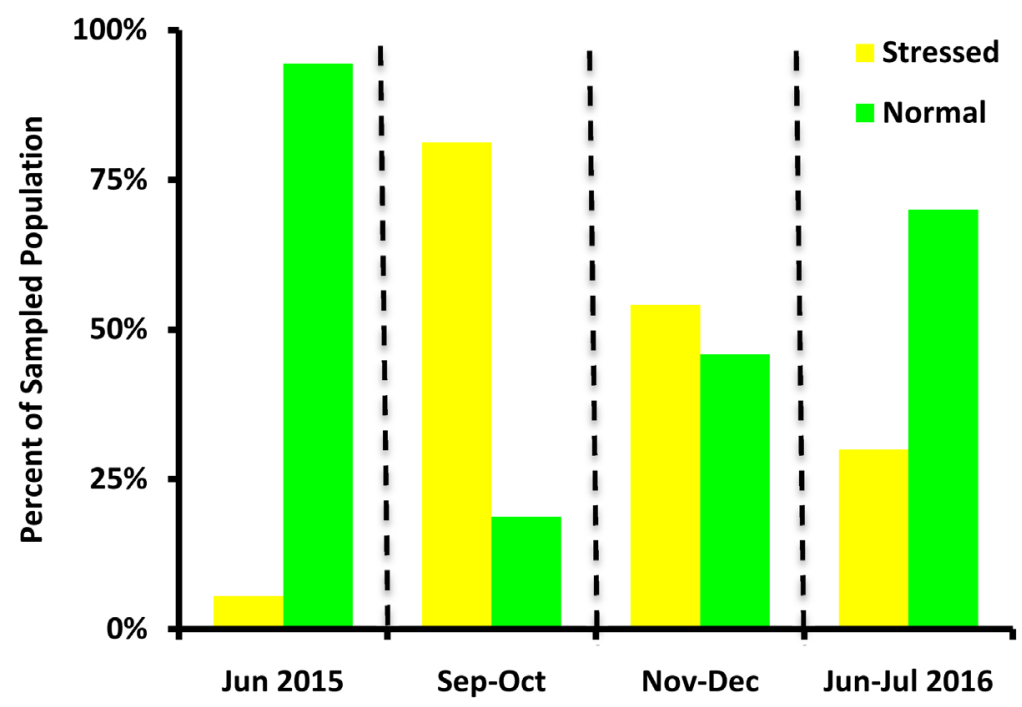

Figure 4. Siderastrea siderea health status in Little Cayman between June 2015 and July 2016. All time frames are statistically significantly different (Wilcoxon-Mann-Whitney analysis). 
$59 \%$ were blue, and a single colony had bleached white. Wilcoxon-Mann-Whitney analyses confirmed the sample population health during this period of stress was statistically significantly different compared to the June 2015 baseline ( $\alpha=0.05 ; P=0.006$ ). Adverse weather during the first week of October resulted in several days of cloud cover and heavy wind, waves, and rain which brought relief to the reef through reduced water temperatures before significant bleaching or mortality occurred.

By November and December, water temperatures within the shallow lagoon and deeper reefs dropped to $28^{\circ} \mathrm{C}-29^{\circ} \mathrm{C}$ and $27^{\circ} \mathrm{C}-28^{\circ} \mathrm{C}$, respectively, below the temperatures during the June assessments. $54 \%$ of the $S$. siderea colonies displayed signs of stress (Figure 4): 25\% were pale, 29\% were blue, and no colonies were fully bleached (white) indicating rapid short-term recovery of $\sim 28 \%$ of the population within two months of the elevated temperature disturbance. Wilcoxon-Mann-Whitney analyses ( $\alpha=$ $0.05)$ confirmed the statistically significant recovery compared to the September-October sample $(P=0.033)$, but the population was still stressed compared to June ( $P=$ $0.010)$. The largest recovery occurred within the blue colonies, with approximately half of those returning to normal color (i.e. 59\% of the surveyed corals were blue in SeptOct compared to $29 \%$ in Nov-Dec).

The $S$. siderea population continued to recover during the first half of 2016 but $30 \%$ of the sampled population remained stressed, five times higher than the June 2015 pre-disturbance baseline (Figure 4). Wilcoxon-Mann-Whitney analyses $(\alpha=0.05)$ confirmed the statistically significant recovery compared to November-December ( $P=$ $0.012)$, but the population had not returned to "normal" $(P=0.006)$. The health status of the surveyed population suggests that more than a year is required for the $S$. siderea population to recover from exposure to elevated temperatures.

Size class frequency distributions indicated that the smallest corals $\left(<200 \mathrm{~cm}^{2}\right.$ surface area) comprised the largest group within the surveyed population (Table 2) and approximately half of the stressed colonies in the June-July 2016 surveys (Figure 5). Wilcoxon-Mann-Whitney analyses $(\alpha=0.05)$ indicated the health status of Size Classes 2 and 6 were statistically significantly similar $(P=0.934)$ as were Size Classes 3 and $4(P=$ $0.167)$ and Size Classes 4 and $5(P=0.075)$. All other size classes were statistically significantly different from each other.

Hierarchical agglomerative cluster analysis revealed that all sites sampled in 2016 shared at least a $40 \%$ similarity based on the percent of stressed colonies in each size class (Figure 6). Four subsets of the population had a $70 \%$ similarity among the sites comprising each respective assemblage (Figure 6). However, when these sites were plotted on the map of Little Cayman (Figure 1), no spatial patterns were discernible based on the assemblages generated by the Bray-Curtis analysis, suggesting that depth and relative site resilience do not influence the prevalence of pale and blue colonies within the population. ANOSIM results confirmed that $S$. siderea health was not statistically different between shallow $(<2 \mathrm{~m}$ depth$)$ and deep $(>6 \mathrm{~m}$ depth$)$ sites $(\mathrm{R}$ statistic $=$ 0.36 ) or between sites with various resilience rankings ( $\mathrm{R}$ statistics $=0.13$ ).

SIMPER analyses identified the $S$. siderea size classes which contributed to the within-group similarities and among-group dissimilarities. Corals with surfaces areas below $200 \mathrm{~cm}^{2}$ (Size Classes 1 and 2) and above $1000 \mathrm{~cm}^{2}$ (Size Class 6) contributed most to 


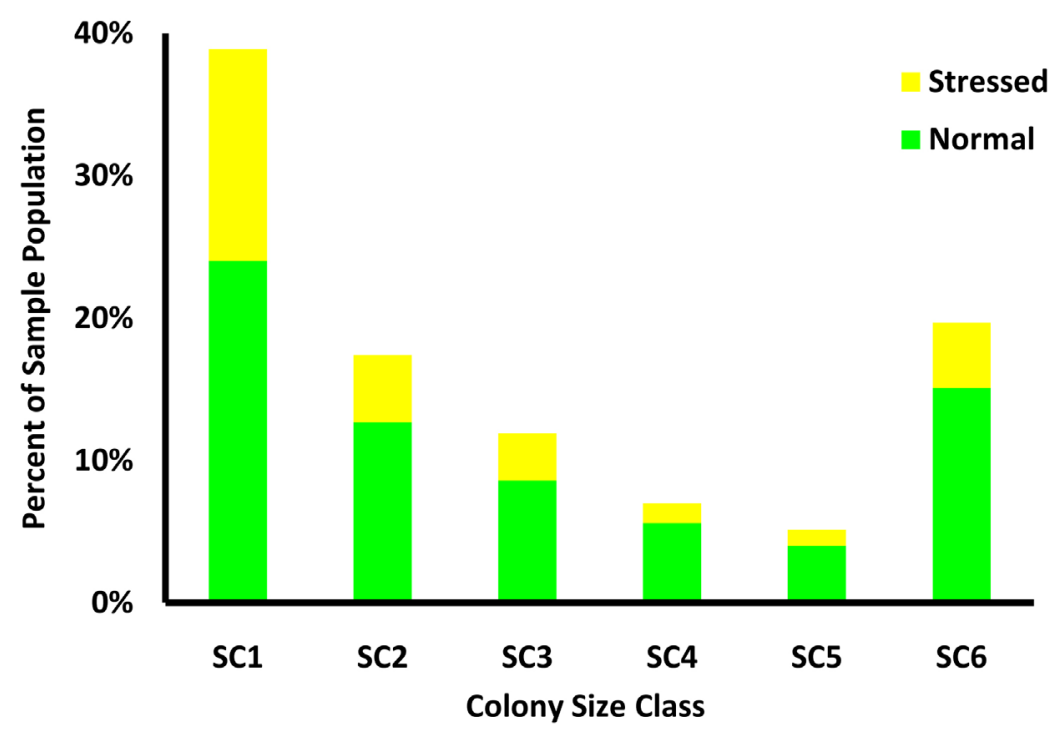

Figure 5. Health status of $S$. siderea in Little Cayman by colony size class distribution in June-July 2016. The health status is statistically similar between size classes (i) SC2 and SC6; (ii) SC3 and SC4 and (iii) SC4 and SC5. All other size classes are statistically significantly different from each other (Wilcoxon-MannWhitney analysis).

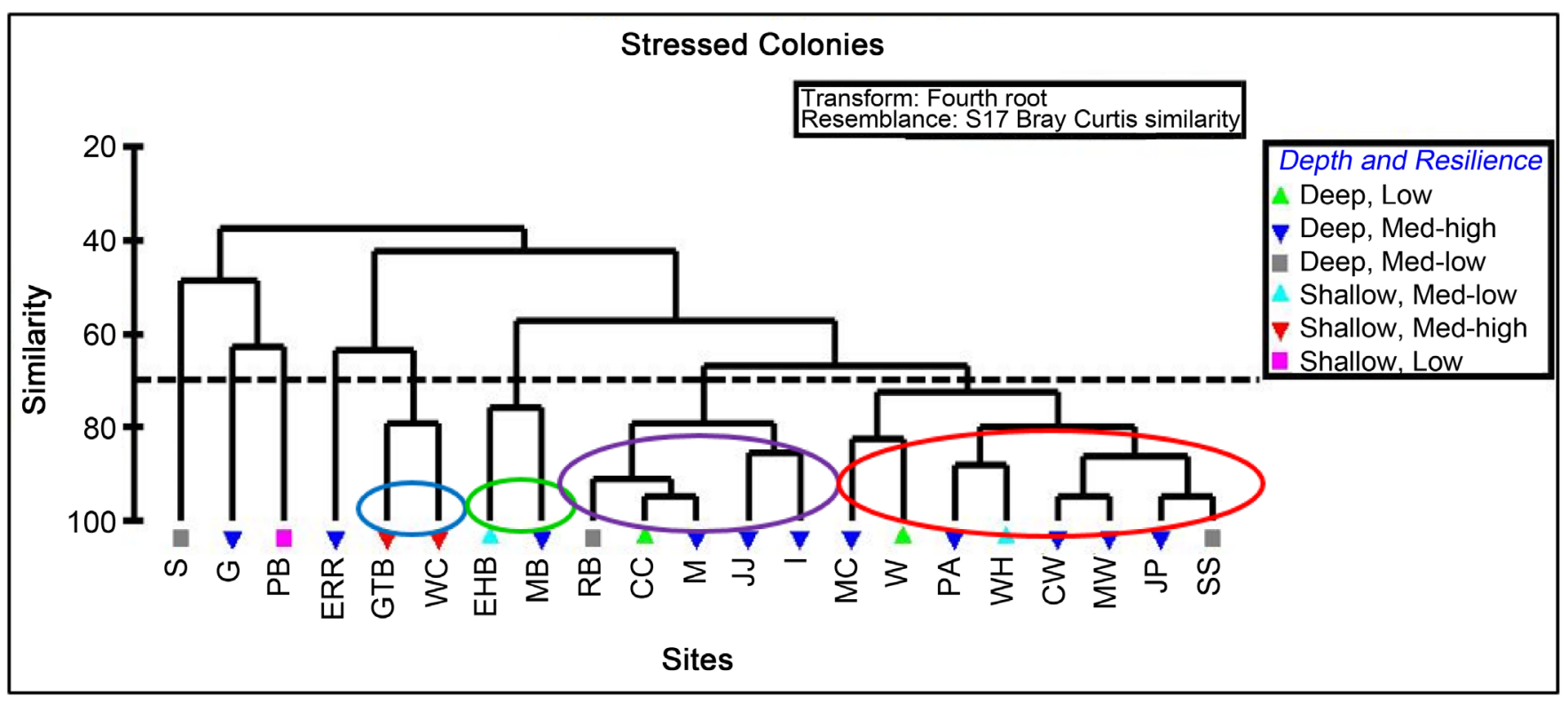

Figure 6. Bray-Curtis similarity cluster analysis depicting four assemblages. Colored ovals represent groups of sites with $>70 \%$ similarity based on health status within six colony size classes.

the (dis)similarities between shallow and deep sites (Table 3). Corals with surfaces areas between $600-1000 \mathrm{~cm}^{2}$ (Size Classes 4 and 5) contributed least to the (dis)similarities between the low, medium-high, and medium-low resilience sites (Table 4).

T-test results show.

\section{Discussion}

Temperature-induced bleaching occurs when the long term average sea surface temperature 
Table 3. Within-group similarities and among-group dissimilarities from SIMPER analysis of depth. Cont. (\%) is the percentage (dis)similarity contributed by the respective size class. Cum. (\%) is the cumulative percentage of (dis) similarity.

\begin{tabular}{|c|c|c|c|c|c|}
\hline \multicolumn{3}{|l|}{ Group A: Deep Sites } & \multicolumn{3}{|c|}{ Groups: Deep vs Shallow } \\
\hline Average similarity: 62.17 & $\begin{array}{r}\text { Cont. } \\
(\%)\end{array}$ & Cum. (\%) & $\begin{array}{l}\text { Average } \\
\text { dissimilarity: } \\
53.10\end{array}$ & $\begin{array}{r}\text { Cont. } \\
(\%)\end{array}$ & Cum. (\%) \\
\hline$S C 1$ & 37.04 & 37.04 & $S C 1$ & 22.22 & 22.22 \\
\hline$S C 2$ & 29.03 & 66.08 & $S C 6$ & 20.28 & 42.51 \\
\hline$S C 3$ & 16.10 & 82.18 & $S C 2$ & 20.18 & 62.68 \\
\hline \multirow[t]{2}{*}{$S C 6$} & 10.14 & 92.32 & $S C 3$ & 15.53 & 78.21 \\
\hline & & & $S C 4$ & 11.70 & 89.92 \\
\hline Group B: Shallow Sites & & & $S C 5$ & 10.08 & 100.00 \\
\hline \multicolumn{6}{|l|}{ Average similarity: 34.04} \\
\hline$S C 6$ & 33.44 & 33.44 & & & \\
\hline$S C 1$ & 27.75 & 61.19 & & & \\
\hline$S C 3$ & 26.86 & 88.05 & & & \\
\hline$S C 2$ & 5.99 & 94.04 & & & \\
\hline
\end{tabular}

(SST) is exceeded by $1^{\circ} \mathrm{C}$ or more during the warmest season, and can be detrimental to the health of the reef ecosystem [1]. However, even a $0.1^{\circ} \mathrm{C}$ rise in sea surface temperature has been reported to increase the average number of coral colonies affected by bleaching by $42 \%$ [2]. In a bleaching event, a coral loses the zooxanthellae that give the colony its color, as well as energy, which may result in the whitening of part or all of a coral's tissue and often times death [15].

The zooxanthellae, however, are not the only source of energy for some species of coral. Endolithic algae have been shown to rise to the coral tissue surface in certain species when zooxanthellae have been expelled during bleaching events. Endolithic algae as well as organic particles from sediment can serve as alternative energy sources in the absence of zooxanthellae allowing some corals to survive bleaching events [16] [17]. The blue bleaching by Siderastrea siderea may be due to the presence of endolithic algae [16], which may contribute to the survival of $S$. siderea during disturbance events.

The study described herein shows that $S$. siderea colonies in Little Cayman are able to withstand and quickly recover from temperature anomalies similar to those experienced in 2015 . While frequent exposure to SSTs above $30.5^{\circ} \mathrm{C}$ caused $76 \%$ of the observed $S$. siderea colonies to pale or bleach blue, only a single colony was observed to bleach white. In the first two months following the return to "normal" seawater temperatures, approximately one third of the stressed $S$. siderea colonies had returned to their healthy brown color. Another one third of the stressed population returned to their healthy brown color 3 - 9 months after the disturbance subsided. SSTs in 2016 stayed below the typical summertime maximum, which will hopefully promote further recovery of the remaining one third of the stressed colonies to pre-disturbance health. 
Table 4. Within-group similarities and among-group dissimilarities from SIMPER analysis of site resilience. Cont. (\%) is the percentage (dis)similarity contributed by the respective size class. Cum. (\%) is the cumulative percentage of (dis)similarity. Site resilience based on six indicators of coral reef resilience: coral diversity, macroalgae cover, coral cover, bleaching resistance, coral recruitment, temperature variability, and herbivore biomass (unpublished data).

\begin{tabular}{|c|c|c|c|c|c|}
\hline \multicolumn{3}{|c|}{ Group A: Low Resilience } & \multicolumn{3}{|c|}{ Groups: Low vs Med-High } \\
\hline $\begin{array}{l}\text { Average similarity: } \\
48.73\end{array}$ & $\begin{array}{l}\text { Cont. } \\
(\%)\end{array}$ & $\begin{array}{l}\text { Cum. } \\
(\%)\end{array}$ & $\begin{array}{l}\text { Average dissimilarity: } \\
53.50\end{array}$ & $\begin{array}{l}\text { Cont. } \\
(\%)\end{array}$ & $\begin{array}{l}\text { Cum. } \\
(\%)\end{array}$ \\
\hline$S C 1$ & 82.34 & 82.34 & $S C 6$ & 24.81 & 24.81 \\
\hline \multirow[t]{2}{*}{$S C 2$} & 17.66 & 100.00 & $S C 1$ & 19.26 & 44.07 \\
\hline & & & $S C 3$ & 18.26 & 62.33 \\
\hline \multicolumn{3}{|c|}{ Group B: Medium-High Resilience } & $S C 2$ & 16.30 & 78.63 \\
\hline \multicolumn{3}{|c|}{ Average similarity: 59.31} & $S C 5$ & 10.91 & 89.53 \\
\hline$S C 2$ & 26.29 & 26.29 & $S C 4$ & 10.47 & 100.00 \\
\hline$S C 1$ & 24.22 & 50.50 & & & \\
\hline$S C 6$ & 21.75 & 72.25 & \multicolumn{3}{|c|}{ Groups: Low vs Med-Low } \\
\hline \multirow[t]{2}{*}{$S C 3$} & 19.42 & 91.67 & Average dissimilarity: & & \\
\hline & & & $S C 3$ & 22.92 & 22.92 \\
\hline \multicolumn{3}{|c|}{ Group C: Medium-Low Resilience } & $S C 2$ & 19.25 & 42.16 \\
\hline \multicolumn{3}{|c|}{ Average similarity: 49.49} & $S C 6$ & 16.96 & 59.12 \\
\hline$S C 1$ & 45.39 & 45.39 & $S C 1$ & 16.29 & 75.41 \\
\hline$S C 3$ & 21.76 & 67.15 & $S C 5$ & 12.45 & 87.86 \\
\hline$S C 2$ & 17.94 & 85.09 & $S C 4$ & 12.14 & 100.00 \\
\hline \multirow[t]{9}{*}{$S C 6$} & 7.58 & 92.68 & & & \\
\hline & & & \multicolumn{3}{|c|}{ Groups: Med-High vs Med-Low } \\
\hline & & & \multicolumn{3}{|c|}{ Average dissimilarity: 43.04} \\
\hline & & & $S C 6$ & 21.24 & 21.24 \\
\hline & & & $S C 1$ & 19.73 & 40.97 \\
\hline & & & $S C 2$ & 17.05 & 58.01 \\
\hline & & & $S C 3$ & 16.36 & 74.37 \\
\hline & & & $S C 4$ & 13.92 & 88.29 \\
\hline & & & $S C 5$ & 11.71 & 100.00 \\
\hline
\end{tabular}

Manfrino et al. [18] recorded similar S. siderea bleaching resistance during the 2005 and 2010 bleaching events in Little Cayman. The hardiness of $S$. siderea leads to survival following certain elevated temperature anomalies which may, in turn, lead to a future phase shift from other dominant reef building corals to $S$. siderea [19], as many of these other species are more susceptible to bleaching and mortality when exposed to non- 
ideal conditions [20].

Other studies have shown that physical stress in a reef ecosystem is more common in shallower versus deeper depths [21]. In southern Belize, S. siderea colonies on the forereef experienced higher susceptibility to stressors than colonies on the shallower backreef and nearshore [22]. In the Florida Keys, land use and water management were determined to affect the quality and amount of freshwater runoff flowing into the bay, thereby causing stress to the shallow, nearshore corals [23]. The lack of depth-dependent stress found in Little Cayman's $S$. siderea population may be due, in part, to the minimal land-based pressures associated with the remote island.

\section{Conclusion}

This study describes the baseline health status within the Siderastrea siderea population around Little Cayman before, during, and after the 2015 elevated temperature anomaly. These data may subsequently be used to compare the health of $S$. siderea during future bleaching events and post-stress recovery periods. This species is an early indicator of stress on the reef and may be used to alert researchers to an impending bleaching event. During "normal" non-disturbance conditions, approximately 6\% of the Little Cayman S. siderea population may appear blue or pale which must be taken into account when assessing the net impacts of a disturbance to coral health. These corals are capable of surviving a five-week exposure to SSTs above the normal summertime maximum, making them one of the more resilient species. Post-disturbance recovery occurs within nine months for roughly two-thirds of the stressed corals. Recovery times for the remaining one-third of the affected corals have not yet been determined. Long-term impacts (e.g. reproduction rates, susceptibility to subsequent stressors) also require future study. If the return to normal color is an indicator for short- and long-term resilience, S. siderea may be among the "winning" coral species following elevated SST anomalies.

\section{Acknowledgements}

The authors thank the Central Caribbean Marine Institue's summer interns and staff as well as the citizen science volunteers from Earthwatch who assisted with the field data collection. Funding for this project was provided in part by the National Science Foundation's Division of Ocean Sciences Research Experience for Undergraduates grant \#1358600, Earthwatch, the National Fish and Wildlife Foundation grant \#43142, and private donations to the UK and US CCMI Research Fund.

\section{References}

[1] Goreau, T.J. and Hayes, R.L. (1994) Coral Bleaching and Ocean "Hot Spots". Ambio-Journal of Human Environment Research and Management, 23, 176-180. http://www.botany.hawaii.edu/basch/uhnpscesu/pdfs/sam/Goreau1994bS.pdf

[2] McWilliams, J.P., Côté, I.M., Gill, J.A., Sutherland, W.J. and Watkinson, A.R. (2005) Accelerating Impacts of Temperature-Induced Coral Bleaching in the Caribbean. Ecology, 86, 2055-2060. https://doi.org/10.1890/04-1657

[3] Fitt, W.K., Brown, B.E., Warner, M.E. and Dunne, R.P. (2001) Coral Bleaching: Interpretation of Thermal Tolerance Limits and Thermal Thresholds in Tropical Corals. Coral Reefs, 20, 51-65. https://doi.org/10.1007/s003380100146 
[4] Hughes, L., Steffen, W. and Rice, M. (2016) Australia's Coral Reefs under Threat from Climate Change. Climate Council of Australia, Ltd., Potts Point, 1-22

[5] Castillo, K.D., Ries, J.B., Bruno, J.F. and Westfield, I.T. (2014) The Reef-Building Coral Siderastrea siderea Exhibits Parabolic Responses to Ocean Acidification and Warming. Proceedings of the Royal Society of London B: Biological Sciences, 281, 1-9.

[6] Thornhill, D.J., LaJeunesse, T.C., Kemp, D.W., Fitt, W.K. and Schmidt, G.W. (2006) Multi-Year, Seasonal Genotypic Surveys of Coral-Algal Symbioses Reveal Prevalent Stability or Post-Bleaching Reversion. Marine Biology, 148, 711-722. https://doi.org/10.1007/s00227-005-0114-2

[7] Hernández-Delgado, E.A., Toledo, C.G., Claudio, H., Lassus, J., Lucking, M.A., Fonseca, J., Hall, K., Rafols, J., Horta, H. and Sabat, A.M. (2006) Spatial and Taxonomic Patterns of Coral Bleaching and Mortality in Puerto Rico during Year 2005. In: Coral Bleaching Response Workshop, Vol. 16, NOAA, St. Croix, USVI.

[8] Foster, K. (2014) 2014 Coral Bleaching Report.

http://reefresearch.org/research/coral-reef-early-warning-system-crews/2014-coral-bleachi ng-report/

[9] Gordeau, T.J. (1992) Bleaching and Reef Community Change in Jamaica: 1951-1991. American Zoologist, 32, 683-695. https://doi.org/10.1093/icb/32.6.683

[10] Hill, J. and Wilkinson, C. (2004) Methods for Ecological Monitoring of Coral Reefs. Australian Institute of Marine Science, Townsville, Version 1, 1-116.

https://www.cbd.int/doc/case-studies/tttc/tttc-00197-en.pdf

[11] Kohler, K.E. and Gill, S.M. (2006) Coral Point Count with Excel Extensions (CPCe): A Visual Basic Program for the Determination of Coral and Substrate Coverage Using Random Point Count Methodology. Computers and Geosciences, 32, 1259-1269. https://doi.org/10.1016/j.cageo.2005.11.009

[12] Clarke, K.R. and Gorley, R.N. (2006) PRIMER v6: User Manual/Tutorial (Plymouth Routines in Multivariate Ecological Research). PRIMER-E, Plymouth.

[13] Clarke, K.R. and Warwick, R.M. (2001) Change in Marine Communities: An Approach to Statistical Analysis and Interpretation. 2nd Edition. PRIMER-E, Plymouth, 1-172

[14] NOAA Coral Health and Monitoring Program (CHAMP) Portal (2016). http://www.coral.noaa.gov/champportal/

[15] van Hooidonk, R.J., Manzello, D.P., Moye, J., Brandt, M.E., Hendee, J.C., McCoy, C. and Manfrino, C. (2012) Coral Bleaching at Little Cayman, Cayman Islands 2009. Estuarine, Coastal and Shelf Science, 106, 80-84. https://doi.org/10.1016/j.ecss.2012.04.021

[16] Fine, M. and Loya, Y. (2002) Endolithic Algae: An Alternative Source of Photoassimilates during Coral Bleaching. Proceedings of the Royal Society of London B: Biological Sciences, 269, 1205-1210. https://doi.org/10.1098/rspb.2002.1983

[17] Foster, A.B. (1980) Environmental Variation in Skeletal Morphology within the Caribbean Reef Corals Montastraea annularis and Siderastrea siderea. Bulletin of Marine Science, 30, 678-709.

[18] Manfrino, C., Jacoby, C.A., Camp, E. and Frazer, T.K. (2013) A Positive Trajectory for Corals at Little Cayman Island. PLoS ONE, 8.

[19] Forsman, Z. (2003) Phylogeny and Phylogeography of Porites \& Siderastrea (Scleractinia: Cnidaria) Species in the Caribbean and Eastern Pacific; Based on the Nuclear Ribosomal ITS Region. Ph.D. Dissertation, University of Houston, Houston.

[20] Hoegh-Guldberg, O. and Salvat, B. (1995) Periodic Mass-Bleaching and Elevated Sea Temperatures: Bleaching of Outer Reef Slope Communities in Moorea, French Polynesia. Marine Ecology Progress Series, 121, 181-190. https://doi.org/10.3354/meps121181

[21] Huston, M.A. (1985) Patterns of Species Diversity on Coral Reefs. Annual Review of Ecol- 
ogy and Systematics, 16, 149-177. http://www.jstor.org/stable/2097046 https://doi.org/10.1146/annurev.es.16.110185.001053

[22] Castillo, K.D., Ries, J.B. and Weiss, J.M. (2011) Declining Coral Skeletal Extension for Forereef Colonies of Siderastrea siderea on the Mesoamerican Barrier Reef System, Southern Belize. PLOS ONE, 6.

[23] Porter, J.W., Lewis, S.K. and Porter, K.G. (1999) The Effect of Multiple Stressors on the Florida Keys Coral Reef Ecosystem: A Landscape Hypothesis and a Physiological Test. Limnology and Oceanography, 44, 941-949.

https://doi.org/10.4319/lo.1999.44.3_part_2.0941

Submit or recommend next manuscript to SCIRP and we will provide best service for you:

Accepting pre-submission inquiries through Email, Facebook, LinkedIn, Twitter, etc. A wide selection of journals (inclusive of 9 subjects, more than 200 journals)

Providing 24-hour high-quality service

User-friendly online submission system

Fair and swift peer-review system

Efficient typesetting and proofreading procedure

Display of the result of downloads and visits, as well as the number of cited articles

Maximum dissemination of your research work

Submit your manuscript at: http://papersubmission.scirp.org/

Or contact ojms@scirp.org 